\title{
THE IMPACT OF DAYLIGHT APERTURES AND REFLECTIVE SURFACES ON THE EFFECTIVENESS OF NATURAL LIGHTING AT THE RUMAH KINDAH OFFICE IN JAKARTA
}

\author{
${ }^{1}$ Diva Melina Panjaitan. ${ }^{2}$ Ir. Mira Dewi Pangestu, MT. \\ ${ }^{1}$ Student in the Bachelor's (S-1) Study Program in Architecture \\ at Parahyangan Catholic University \\ 2 Senior lecturer in the Bachelor's (S-1) Study Program in Architecture \\ at Parahyangan Catholic University
}

\begin{abstract}
Illumination forms an important factor in a building. Lighting, and especially its natural form, is an important element to be considered in an office building. Proper natural lighting in an office can create a way to economize on energy. Besides, it may create a conducive atmosphere, affecting the work spirit and inspire the zest of the employees, so a lighting system must be designed to reach the highest possible degree of effectiveness. The effectiveness of natural lighting can be regarded from the quantitative and qualitative angle. Attaining the purpose of naturadaylight is influenced by various factors, including the daylight apertures that let daylight or sunlight seep in, along with surfaces or panels that reflect light so that it bounces back. Therefore, we must find out how these daylight apertures and reflective surfaces influence the effectiveness of lighting in office buildings. The Rumah Kindah office in Jakarta happens to be one of the office buildings that make use of natural lighting with daylight apertures that are unique, along with several kinds of reflective surfaces.

This type of research can be classified as descriptive-evaluative, making use of the quantitative-qualitative approach. The Rumah Kindah office as the object of rsearch consists of three work spaces displaying the characteristics of daylight apertures that are uniform but not exactly the same, and the same applies to the reflective surfaces, so the research was conducted in these three office rooms. The relevant set of data was collected by way of observation, taking measurements and through the medium of interviews held at the object of research as well as using software to support simulation for the sake of acquiring the data required. These data can be analyzed by employing the theories that are available.

The analysis results indicate that the daylight apertures oriented to the East-West but differing in terms of type, position, dimension and material produce a quantity and quality that varies from space to space. Besides, the reflective surfaces inside and outside the rooms play an important role in attaining the desired effectiveness of natural lighting in each of the work spaces at the Rumah Kindah office in Jakarta.
\end{abstract}

Keywords : Light Apertures, Reflective Surfaces, Effectiveness of Natural Lighting

\section{PENGARUH LUBANG CAHAYA DAN BIDANG REFLEKSI TERHADAP EFEKTIVITAS PENCAHAYAAN ALAMI DI RUMAH KINDAH OFFICE JAKARTA}

\author{
${ }^{1}$ Diva Melina Panjaitan. ${ }^{2}$ Ir. Mira Dewi Pangestu, MT. \\ ${ }^{1}$ Mahasiswa S1 Program Studi Arsitektur Universitas Katolik Parahyangan. \\ ${ }^{2}$ Dosen Pembimbing S1 Program Studi Arsitektur Universitas Katolik Parahyangan.
}

\begin{abstract}
Abstrak- Pencahayaan merupakan faktor yang penting dalam sebuah bangunan. Pencahayaan, khususnya pencahayaan alami merupakan unsur yang penting dalam bangunan kantor. Pencahayaan alami yang baik pada kantor, dapat menciptakan penghematan energi. Selain itu, pencahayaan alami yang baik juga dapat menciptakan suasana yang baik sehingga berpengaruh pada semangat kerja para pekerjanya, maka dirancang sistem pencahayaan agar tercapainya efektivitas pencahayaan. Efektivitas pencahayaan alami dapat ditinjau dari sisi kuantitatif-kualitatif. Pemenuhan tujuan cahaya alami secara kuantitatif-kualitatif dipengaruhi oleh berbagai faktor, termasuk lubang cahaya dan bidang-bidang yang mungkin memantulkan cahaya. Oleh karena itu, perlu
\end{abstract}

\footnotetext{
${ }^{1}$ Corresponding Author: divamelinap@gmail.com
} 
dicari bagaimana lubang cahaya dan bidang refleksi tersebut mempengaruhi efektivitas pencahayaan pada bangunan kantor. Rumah Kindah Office, Jakarta merupakan salah satu kantor yang menggunakan pencahayaan alami dengan lubang cahaya yang unik dengan beberapa macam bidang refleksi.

Jenis penelitian ini adalah deskriptif-evaluatif dengan pendekatan kuantitatif-kualitatif. Rumah Kindah Office sebagai objek penelitian memiliki tiga ruang kerja dengan karakteristik lubang cahaya yang seragam namun tidak sama, begitu pula dengan bidang refleksi, maka dilakukan penelitian pada ketiga ruang kerja tersebut. Pengambilan data dilakukan dengan cara observasi, pengukuran dan wawancara di objek penelitian, serta penggunaan perangkat lunak untuk mendukung simulasi demi keperluan data. Data yang didapat dianalisa dengan menggunakan teori yang sudah ada.

Dari hasil analisa, didapatkan bahwa lubang cahaya dengan orientasi timur-barat namun jenis, posisi, dimensi, dan material yang berbeda memberikan kuantitas dan kualitas cahaya yang berbeda pada tiap ruang. Selain itu, bidang refleksi di dalam maupun luar ruang juga memberikan peran penting dalam pencapaian efektivitas pencahayaan alami di tiap ruang kerja di Rumah Kindah Office, Jakarta.

Kata-kata kunci : Lubang Cahaya, Bidang Refleksi, Efektivitas Pencahayaan Alami

\section{PENDAHULUAN}

\subsection{LATAR BELAKANG PENELITIAN}

Pencahayaan merupakan faktor yang penting dalam sebuah bangunan. Pencahayaan selain berguna sebagai penunjang aktivitas pengguna di dalam ruangan, juga dapat berguna sebagai pembentuk visual estetis, serta memberikan kenyamanan dan keamanan bagi pengguna bangunan.

Dalam bangunan, pemenuhan kebutuhan akan pencahayaan dapat dipenuhi dengan pencahayaan alami dan pencahayaan buatan. Penggunaan pencahayaan buatan pada dasarnya mengkonsumsi banyak energi. Dengan maraknya isu pengehematan energi belakangan ini, seharusnya desain bangunan mempertimbangkan efisiensi energi dengan memaksimalkan penggunaan pencahayaan alami.

Pencahayaan merupakan unsur yang penting dalam bangunan kantor. Dengan pencahayaan yang baik pekerja di dalam kantor dapat bekerja dengan lebih efektif, selain itu pencahayaan yang baik dapat menciptakan suasana yang baik sehingga berpengaruh pada semangat kerja para pekerjanya. Studi pada bangunan kantor di Hawai menyebutkan bahwa $27 \%$ dari total konsumsi energi bangunan tergunakan untuk pencahayaan buatan. Tingginya konsumsi energi yang digunakan untuk pencahayaan buatan mendorong penggunaan pencahayaan alami pada bangunan kantor.

Penggunaan pencahayaan alami ini didukung dengan negara Indonesia yang beriklim tropis lembab. Letaknya yang dilewati garis khatulistiwa menyebabkan Indonesia mendapat suplai cahaya matahari sepanjang tahun. Namun cahaya matahari yang tersedia terkadang tidak sesuai dengan kebutuhan, dapat berlebih maupun kurang. Maka dilakukan perencanaan dan perancangan sistem pencahayaan alami pada bangunan, terutama bangunan kantor. Sistem pencahayaan alami ini dirancang agar tercapainya tujuan dari penggunaan pencahayaan alami yang selanjutnya disebut efektivitas pencahayaan alami. Efektivitas pencahayaan alami dapat ditinjau dari sisi kuantitatif yaitu memenuhi intenitas cahaya sesuai dengan standar yang ada, selain itu dari sisi kualitatif yaitu dengan kemerataan cahaya dalam ruangan dan rasio kecerlangan serta kontrol terhadap silau.

Pemenuhan tujuan cahaya alami secara kuantitatif dan kualitatif dipengaruhi oleh berbagai faktor, termasuk lubang cahaya dan bidang-bidang yang mungkin memantulkan cahaya. Lubang cahaya memiliki peran penting dalam masuknya cahaya ke dalam ruang, sedangkan bidang-bidang yang terdapat di dalam maupun luar ruangan memiliki peran pula dalam memantulkan cahaya sehingga cahaya dapat masuk ke dalam ruangan. Faktor-faktor tersebut dapat direncanakan dan dirancang dalam sebuah bangunan demi tercapainya 
efektivitas pencahayaan. Salah satu bangunan yang melakukan perencanaan dan perancangan sistem pencahayaan alami adalah Rumah Kindah Office.

\subsection{TUJUAN MASALAH}

Tujuan dari penelitian ini adalah untuk mengetahui pengaruh lubang cahaya dan bidang refleksi terhadap efektivitas pencahayaan di dalam Rumah Kindah Office.

\section{ANALISA}

\subsection{RUMAH KINDAH $O F F I C E$}
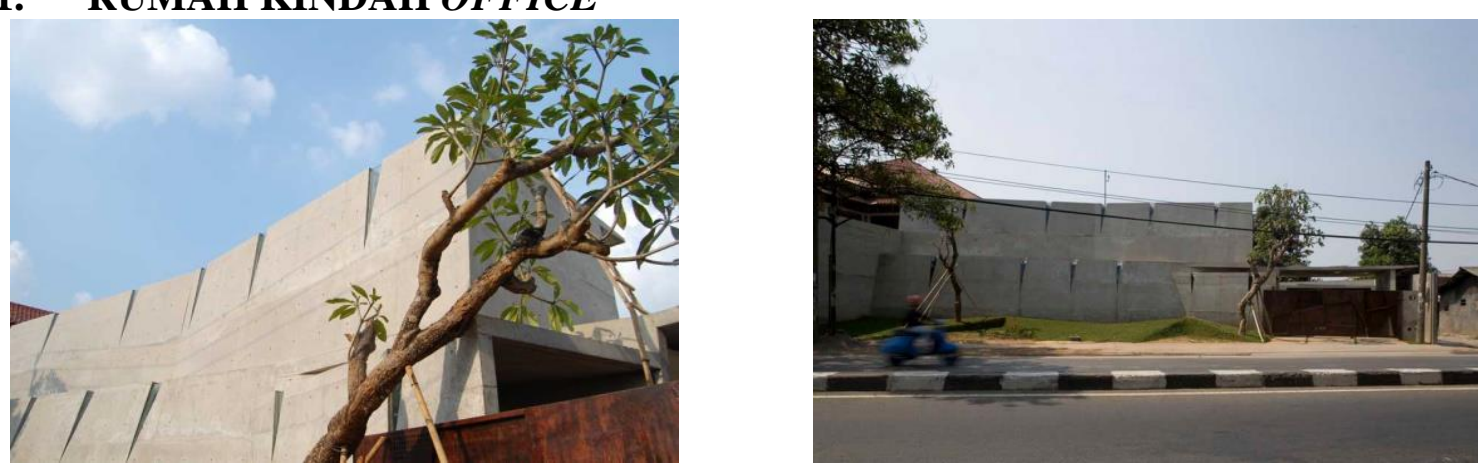

Figur 1. Tampak Depan Rumah Kindah Office

Rumah Kindah Office merupakan bangunan kantor PT. Kindah Abadi Utama. Kantor ini terdiri dari lima ruang kerja, dua ruang rapat, dan ruang-ruang penunjang lainnya. Data proyek tersebut adalah sebagai berikut:
a. Lokasi
: Jl Raya Lenteng Agung no 99, Tanjung Barat,
b. Fungsi Jakarta Selatan
c. Luas bangunan
: Kantor
d. Arsitek
: $610 \mathrm{~m}^{2}$
e. Klien
: Budi Pradono
: Roni Aidil

Pemilihan Rumah Kindah Office sebagai objek penelitian dilakukan dengan pertimbangan sebagai berikut:

a. Kantor ini memiliki bentuk lubang cahaya yang unik sesuai dengan konsep bangunannya. Kantor ini dirancang dengan konsep kertas lipat yang di gunting menghasilkan bentuk seperti sobekan pada selubung bangunannya. Sobekan tersebut merupakan lubang-lubang cahaya yang digunakan untuk memasukkan cahaya ke dalam ruangan pada siang hari. Selain itu, ruang-ruang di dalam bangunan didesain sedemikian rupa sehingga membuat orientasi ke ruang internal yaitu ruang terbuka berupa taman. Hal ini memungkinkan masuknya cahaya melalui ruang terbuka tersebut. Sehingga dapat dikatakan bahwa kantor ini menggunakan konsep pencahayaan alami

b. Rumah Kindah Office mendapat beberapa penghargaan pada bidang arsitektur diantaranya penghargaan dalam World Festival Awards 2008 pada kategori kantor, Silver Medal dari World Triennial of Architecture Triennale Mondiale De L'architecture

Dengan konsep pencahayaan alami, kantor ini masih menunjukkan adanya ketidaknyamanan secara visual pada jam-jam tertentu di beberapa ruangan. Ruang-ruang kerja yang terus nyaman dan tidak nyaman memiliki beberapa persamaan dan perbedaan pada 
karakteristik fisik di dalam dan luar ruangan tersebut. Oleh karena itu, objek ini menarik untuk dibahas karena dapat diketahui karakteristik fisik yang mempengaruhi efektivitas pencahayaan di dalam ruang-ruang tersebut.

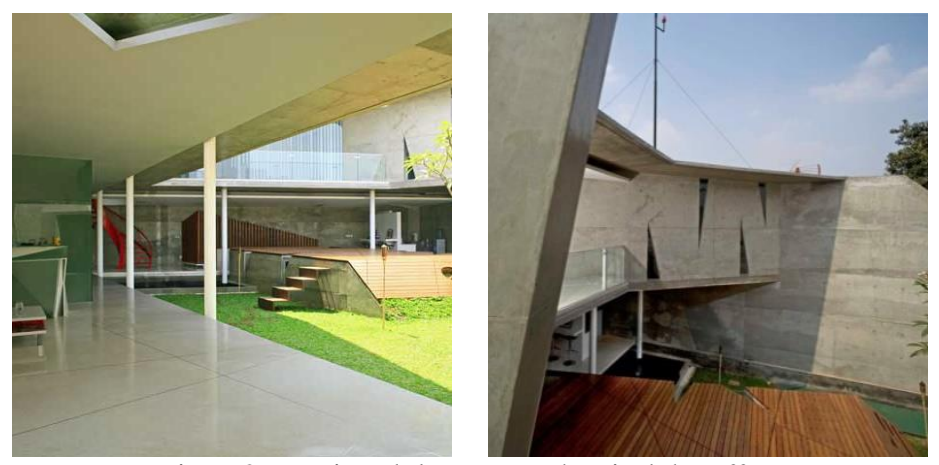

Figur 2. Bagian dalam Rumah Kindah Office

Rumah Kindah Office sebelumnya pernah diteliti oleh mahasiswa Universitas Katolik Parahyangan bernama RR. Dwina Oktaviani sebagai bahan skripsi pada tahun 2010 dengan judul 'Kajian penerapan penanggulangan kebisingan pada desain bangunan : objek studi Kindah Office' yang fokus pada topik kenyamanan audial, sedangkan penelitian kali ini lebih difokuskan kepada pencahayaan alami pada Rumah Kindah Office.

\subsection{PENCAHAYAAN ALAMI}

Cahaya merupakan suatu gelombang elektromagnetik. Satuan kuat cahaya yang dikeluarkan oleh sumber cahaya adalah lumen, namun lumen tidak mendeskripsikan bagaimana keluaran cahaya terdistribusi. Kandela merupakan satuan yang mendeskripsikan intensitas sinar pada semua arah. Ketika lumen dari suatu sumber cahaya menerangi permukaan, maka jumlah kekuatan cahaya yang jatuh pada setiap meter persegi permukaan adalah iluminasi. Iluminasi dipakai dalam penelitian ini untuk pengukuran kuantitatif. Brightness (kecerlangan) atau luminasi merupakan tingkat terang cahaya yang dilihat atau masuk ke dalam mata orang yang melihatnya. Kecerlangan dipengaruhi oleh kualitas cahaya sehingga terkadang berbeda dengan tingkat iluminasi. (Lechner, 2003).

Dalam Arsitektur, pencahayaan terbagi menjadi dua, yaitu pencahayaan alami dan pencahayaan buatan. Pencahayaan alami merupakan pencahayaan yang berasal dari cahaya matahari dan cahaya alam lain. Pencahayaan buatan merupakan pencahayaan yang berasal dari cahaya lampu ataupun penerangan buatan. Pada penelitian kali ini, akan dibahas cahaya pada pencahayaan alami.

Menurut Szokolay (2004), terdapat beberapa sumber cahaya alami utama yang dapat dimanfaatkan, yaitu diantaranya:

- Sunlight, yaitu cahaya matahari langsung dengan tingkat cahaya tinggi

- Skylight, yaitu cahaya matahari yang sudah tersebar dan dipantulkan atmosfer menjadi terang langit dengan tingkat cahaya rendah

- Reflected light, yaitu cahaya matahari yang sudah dipantulkan baik di luar maupun di dalam bangunan

Pada negara-negara beriklim tropis seperti Indonesia yang mendapat suplai matahari sepanjang tahun, biasanya dominan pemanfaatan skyight karena sunlight membawa panas matahari. Pemanfaatan cahaya alami ini dapat didesain agar tercapainya tujuan pencahayaan alami secara efektif atau selanjutnya disebut dengan efektivitas pencahayaan.

Efektivitas pencahayaan dapat dinilai secara kuantitatif dan kualitatif. Kuantitas cahaya yang dimaksud adalah tingkat intensitas cahaya yang terdapat pada bidang kerja. Secara kualitas adalah kemerataan cahaya dalam ruang, rasio kecerlangan dan adanya 
kemungkinan-kemungkinan silau. Hal ini pun dipengaruhi oleh lubang cahaya pada ruangan, dan bidang refleksi yang ada pada luar dan dalam bangunan.

Secara umum, kondisi tapak mempengaruhi masuknya cahaya ke dalam bangunan, namun yang menjadi hal penting adalah bagaimana selubung bangunan dan interior ruangan mengantar cahaya hingga sampai ke bidang kerja sesuai dengan yang dibutuhkan. Pada selubung bangunan yang dapat mempengaruhi adalah jenis, orientasi, posisi, dimensi dan material dari lubang cahaya yang ada. Pada interior ruangan yang dapat mempengaruhi adalah penataan ruang dan material yang digunakan pada bagian dalam ruangan tersebut. Faktor-faktor tersebut dapat mempengaruhi karena adanya sifat cahaya yaitu refleksi (pemantulan) dan transmisi (penerusan)..

\subsection{LUBANG CAHAYA}

Penerapan pemasukan cahaya kedalam bangunan melalui selubung bangunan memiliki beberapa teknik, baik pasif maupun aktif. Semakin besar bukaan atau bidang transparan, tentu akan semakin besar jumlah cahaya yang akan masuk ke dalam ruangan. Selain dimensi lubang cahaya, terdapat faktor penting lain yang mempengaruhi proses masuknya cahaya ke dalam ruang. Hal ini disebabkan cahaya yang dibutuhkan dalam ruangan tidak hanya dinilai secara kuantitas namun kualitasnya pula. Faktor-faktor tersebut antara lain jenis, orientasi, posisi, dimensi, dan material lubang cahaya.

\section{Orientasi Lubang Cahaya}

Acuan dan dasar penetapan orientasi lubang cahaya dibuat berdasarkan orientasi geografi dengan memperhatikan pergerakan matahari lokasi setempat yang akan berpengaruh pada distribusi pencahayaan alami. Berdasarkan pandangan ini, orientasi Timur dan Barat secara umum akan memberikan dampak yang sama, meskipun seringkali arah Barat lebih sering dihindari akibat radiasi panas berlebih.

\section{Jenis Lubang Cahaya}

Jenis lubang cahaya dapat dikategorikan melalui beberapa teknik pemasukan cahaya alami diantaranya side lighting, roof and top lighting, angled lighting, beam lighting, indirect lighting, dan atria, light court dan reentrant lighting. Pada bangunan yang diteliti, teknik pemasukan cahaya yang dipakai adalah side lighting, dan roof and top lighting.

\section{a. Side Lighting}

Pencahayaan ini menggunakan permukaan dinding bangunan untuk menempatkan lubang cahaya yang biasanya dirancang untuk memasukkan sinar horizontal terhadap bidang kerja. Pola distribusi pencahayaan ini merupakan kombinasi antara penetrasi dan sudut penyebaran (letitudinal spread) sinar matahari melalui bukaan. Memasukkan cahaya dari sisi samping lebih mudah karena terkoordinasi dengan kulit bangunan dan kerap dipertimbangkan sebagai akses visual bagi pemandangan yang ada di luar bangunan. Pada konsep minimalis, penggunaan kaca sebagai bidang vertikal dan pelingkup bangunan makin sering dilakukan. Cahaya dari samping tergantung pada posisi matahari dan pantulan dari permukaan di luar bangunan. Sebagian besar cahaya yang massuk dari sisi samping bukanlah cahaya matahari langsung (sunlight), melainkan cahaya langit (skylight). Cahaya matahari langsung yang masuk tergantung dengan posisi jendela dan hanya pada jam-jam tertentu.

b. Roof and Top Lighting

Lubang cahaya terletak pada bagian atas atau atap bangunan. Biasa disebut sebagai skylight dan ditempatkan di atas permukaan bidang kerja horizontal. Cahaya yang dimasukkan dari atas umumnya memiliki kuanntitas cahaya yang lebih tinggi 
dibanding cahaya yang dimasukkan dari bagian samping. Cahaya yang masuk merupakan kombinasi cahaya matahari dan cahaya langit. Kondisi ini menyebabkan cahaya alami yang masuk memiliki intensitas tinggi yang relatif stabil sepanjang hari. Distribusi cahaya yang dimasukkan melalui top lighting akan lebih merata apabila disebar dengan menambahkan bidang refleksi pada bagian bawah plafon. Tanpa bidang refleksi, cahaya yang masuk akan terkonsentrasi pada titik tertentu dan akan memicu silau pada area-area tertentu.

\section{Posisi Lubang Cahaya}

Pada suatu ruangan yang mendapatkan pencahayaan dari langit melalui lubang-lubang cahaya di beberapa dinding, masing-masing dinding memiliki bidang lubang cahaya efektif masing-masing. Perluasan daerah distribusi cahaya dalam ruangan dapat diperoleh dengan cara arah cahaya lebih dari satu arah bukaan sehingga membantu distribusi cahaya dan mengurangi kontras terang-gelap antara luar dan dalam (Lechner, 2007). Posisi lubang cahaya dapat digambarkan berdasarkan posisi vertikal dan horizontalnya pada dinding. Mengacu pada posisinya terhadap bidang vertikal, lubang cahaaya berupa jendela dapat diklasifikasikan berdasarkan:

a. Jendela tinggi

Jendela tinggi memberikan penetrasi terdalam untuk direct lighting dan diffuse light. Lubang cahaya tinggi mampu menghasilkan efisiensi pencahyaan alami yang paling terang karena berada di atas ketinggian mata manusia. Bagi jendela tinggi, potensi silau datang langsung ketika sinar matahari terpapar langsung ke bidang lubang cahaya.

b. Jendela menengah

Jendela tengah memberikan cahaya yang cukup untuk tujuan ruangan dan paling sering dipakai dan disukai. Hal ini disebabkan karena pada umumnya memberikan tampilan terbaik bagi ruang dan memberikan viewing yang paling nyaman. Dari aspek maintenance pun lebih mudah dibandingkan dua jendela yang lain.

c. Jendela rendah

Jendela rendah memberikan iluminasi yang paling merata ke dalam ruangan dengan mendistribusikan refleksi cahaya ke dalam ruangan. Namun penetrasi cahaya maksimal hanya terjadi di dekat jendela dan berada di bawah ketinggian mata manusia. Sehingga beberapa bagian di ruangan kurang menerima cahaya dan ruangan terkesan gelap. Jendela rendah memiliki kelemahan utama yaitu menimbulkan potensi silau yang tinggi akibat pantulan yang terjadi.

\section{Dimensi Lubang Cahaya}

Jumlah cahaya yang masuk ke dalam ruangan dipengaruhi oleh refleksi dinding dan plafon, penempatan dan ukuran lubang cahaya, proporsi dan ukuran ruangan, dan hambatan dari luar. Kedalaman ruang yang terbentuk mempengaruhi distribusi cahaya dalam ruangan tersebut. Semakin jauh dari lubang cahaya, maka iluminasi yang dihasilkan akan semakin rendah (Baker, 1993). Kedalaman ruang maksimum adalah 2 sampai 2.5x tinggi lubang cahaya agar tingkat iluminasi minimal dan distribusi cahayanya merata. Luas lubang cahaya harus dibatasi 10\% hingga 20\% luas dinding karena iluminasi eksterior seringkali 500x lebih banyak daripada yang diperlukan di bagian dalam.

Sebuah ruangan dengan proporsi standar dan reflektansi permukaan $40 \%$ tanpa hambatan luar akan mengakibatkan jumlah rata-rata cahaya dalam ruang adalah berbanding langsung dengan luas bidang kaca. Sedangkan lubang cahaya yang besar terhadap luas 
dinding, nilai yang dipantulkan rata-rata dari permukaan interior dibawah $40 \%$ dan luas bidang kaca menjadi suatu indikator yang kurang tepat bagi iluminasi rata-rata.

Menurut Baker (1993), permukaan multak (absolute surface) dengan penetrasi (fenestration) memiliki perbedaan. Jumlah jendela yang berhubungan dengan ruang yang diterangi dari cahaya jendela digambarkan dengan persentase. Permukaan mutlak jendela hanya akan mempengaruhi penghawaan dan pandangan keluar, sedangkan penetrasi akan mempengaruhi jumlah dan distribusi cahaya. Dapat disimpulkan secara umum, penetrasi tinggi dan penetrasi sangat tinggi justru akan menimbulkan masalah berupa ketidaknyamanan termal dan efek silau. Karena itu sistem pengaturan cahaya dapat digunakan untuk mencegah masalah ini.

\section{Material Lubang Cahaya}

Material lubang cahaya berpengaruh pada cahaya yang masuk ke dalam ruangan melalui besar transmisi cahaya material tersebut. Pada medium transparan seperti udara, cahaya akan terpancar lurus. Pada Inverse Square Law intensitas cahaya akan berkurang seriring dengan jaraknya terhadap sumber cahaya, apabila sumber cahaya berjarak 2 kali lipat maka area penerangan akan lebih besar 4 kali lipat. Hal inilah yang disebut sebagai transmisi cahaya.

Klasifikasi material pada transmisi cahaya terbagi menjadi tiga yaitu Transparan, Opaque, dan Translucent. Semakin tebal material tersebut, cahaya yang ditransmisi akan semakin sedikit.

Tabel 1. Transmisi Material Lubang Cahaya

(Sumber: Mangunwijaya, 2000)

\begin{tabular}{|l|l|l|l|}
\hline Bahan & Tebal $(\mathrm{mm})$ & Transmisi $(\%)$ & $\begin{array}{l}\text { Tingkat } \\
\text { Penyebaran Cahaya }\end{array}$ \\
\hline Kaca Polos Terang & $1-4$ & $90-92$ & - \\
\hline Kaca matte es & $2-3$ & $78-68$ & + \\
\hline
\end{tabular}

\subsection{BIDANG REFLEKSI}

Menurut Mangunwijaya (2000), cahaya siang hari (cahaya alami) terdiri dari banyak macam unsur, di antaranya:

- Unsur penerangan yang datang langsung dari langit, termasuk pantulan-pantulan awan

- Unsur refleksi luar, yaitu hasil pemantulan cahaya dari benda-benda yang berdiri di luar rumah kita, dan masuk melalui jendela ke dalam ruangan

- Unsur refleksi dalam, yaitu cahaya yang di pantulkan oleh benda-benda yang terletak rendah (tanah, halaman, rumput, ubin jalan ke pintu dan sebagainya), dipantulkan melalui jendela dan lubang-lubang lain serta menerangi langit-langit dan bagian atas kemudian terpantul lagi dan menerangi bidang kerja.

- Unsur bahan jendela

Refleksi adalah peristiwa terpantulnya cahaya ketika mengenai suatu permukaan. Jumlah cahaya yang di refleksikan pada suatu permukaan ditunjukkan dengan faktor refleksi (RF), yaitu perbandingan besar cahaya yang dipantulkan dengan besar cahaya yang diterima permukaan. 


\section{Faktor Refleksi Luar}

Faktor Refleksi Luar dipengaruhi oleh ukuran lubang cahaya, ukuran penghalang, reflektansi cahaya dari permukaan penghalang, dan posisi titik tersebut pada bidang kerja. Permukaan yang berwarna terang memantulkan cahaya siang dapat meningkatkan tingkat pencahayaan dalam ruangan (Soegijanto, 1998). Faktor Refleksi Luar dihitung melalui titik pada bidang kerja dengan angka perbandingan antara tingkat pencahayaan yang ditimbulkan komponen cahaya yang datang padatitik tersebut melalui pantulan dari penghalang di luar bangunan terhadap tingkat pencahayaan pada bidang horisontal di tempat terbuka yang sama.

\section{Faktor Refleksi Dalam}

Cahaya yang dipantulkan pada refleksi dalam dapat berupa cahaya langsung dari langit maupun cahaya yang terlebih dahulu dipantulkan oleh permukaan luar yang masuk ke dalam ruangan. Faktor Refleksi Dalam dihitung melalui komponen cahaya yang datang pada suatu titik pada bidang kerja melalui pantulan dari permukaan di dalam ruangan (Soegijanto, 1998). Besarnya dipengaruhi oleh reflektansi cahaya dari semua permukaan dalam ruangan, ukuran ruangan, dan ukuran lubang cahaya.

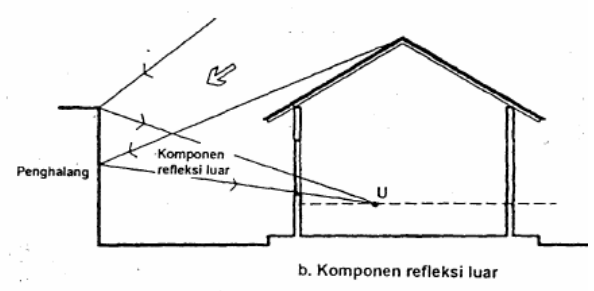

Figur 3. Faktor Refleksi Luar

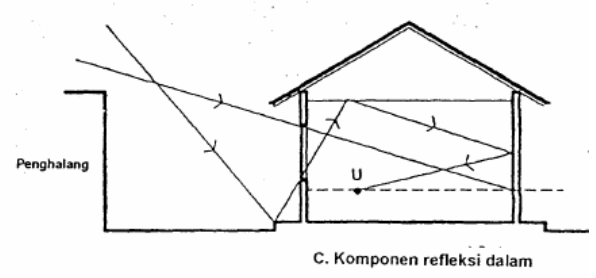

Figur 4. Faktor Refleksi Dalam

\section{Pengaruh Keadaan Bidang Refleksi}

\section{a. Jenis}

Jenis bidang refleksi dapat berupa lantai, plafon, dinding, maupun furnitur yang terdapat dalam ruangan tersebut. Daya pantulan dari permukaan bidang refleksi ini menjadi sangat penting untuk meningkatkan komponen yang dipantulkan dari faktor cahaya pada siang hari. Bidang lantai merupakan elemen yang tidak dianjurkan memiliki daya pantul tinggi. Hal ini disebabkan apabila cahaya yang dipantulkan lantai tinggi dan langsung mengarah ke mata dapat menyebabkan ketidaknyamanan visual.

b. Warna

Umumnya, semakin putih atau semakin muda warna bidang refleksi maka semakin banyak komponen cahaya yang dipantulkan. Hal ini berdampak pada pencahayaan dalam ruangan tersebut menjadi semakin terang. Namun perlu diperhatikan apabila cahaya yang terdapat dalam ruangan terlalu terang dapat menyebabkan silau.

Tabel 2. Daya Pantulan Warna

(Sumber: G.Z. Brown, 1990)

\begin{tabular}{|l|l|}
\hline \multicolumn{1}{|c|}{ Warna } & \multicolumn{1}{c|}{ Daya Pantul (\%) } \\
\hline Putih & $80-90$ \\
\hline Kuning Muda, Ros & 80 \\
\hline 'Beige' Muda, Lilac & 70 \\
\hline Kuning 'mustard' & 35 \\
\hline Coklat Sedang, Abu-abu & 25 \\
\hline Hitam & 10 \\
\hline
\end{tabular}




\section{c. Tekstur}

Tekstur berkaitan erat dengan material yang akan dipakai sebagai finishing bidang refleksi. Dalam kaitannya dengan pencahayaan, tekstur yang licin akan menghasilkan pantulan cahaya yang lebih maksimal. Sedangkan tekstur kasar ataupun matte akan lebih memencarkan pantulan cahaya atau difus (Mangunwijaya, 2000).

Tabel 3. Tekstur (Material) Tidak Tembus Cahaya

(Sumber: Mangunwijawa, 2000)

\begin{tabular}{|c|c|c|c|}
\hline Bahan & Refleksi \% & Penyebaran Cahaya & Pemantulan \\
\hline Alumunium sangat mengkilau & $80-85$ & - & +++ \\
\hline Aluminium buram & $55-65$ & +++ & - \\
\hline Email putih & $65-75$ & ++ & + \\
\hline Gips putih buram & $85-95$ & +++ & - \\
\hline Kertas putih buram & $70-80$ & ++ & + \\
\hline Kertas putih & $70-80$ & + & ++ \\
\hline Granit & $20-25$ & + & \\
\hline Kayu mahoni dipoles & $6-12$ & + & \\
\hline Bahan hitam & $0-0,5$ & - & \\
\hline Beton kasar & $20-30$ & +++ & \\
\hline \multicolumn{4}{|c|}{$\begin{array}{l}\text { Catatan : Nilai-nilai tersebut diukur bila cahaya jatuh tegak lurus } \\
\text { - Sangat lemah } \\
\text { + lemah } \\
\text { ++ sedang } \\
\text { +++ kuat }\end{array}$} \\
\hline
\end{tabular}

Tabel 4. Tekstur (Material) Tembus Cahaya

(Sumber: Mangunwijawa, 2000)

\begin{tabular}{|l|c|c|c|}
\hline \multicolumn{1}{|c|}{ Bahan } & Tebal $(\mathbf{m m})$ & Refleksi $(\boldsymbol{\%})$ & $\begin{array}{c}\text { Tingkat } \\
\text { Penyebaran } \\
\text { Cahaya }\end{array}$ \\
\hline Kaca Polos Terang & $1-4$ & $6-8$ & - \\
\hline Kaca matte es & $2-3$ & $12-20$ & + \\
\hline
\end{tabular}

\subsection{EFEKTIVITAS PENCAHAYAAN}

Pengertian efektivitas adalah pencapaian tujuan secara tepat. Efektivitas bisa juga diartikan sebagai pengukuran keberhasilan dalam pencapaian tujuan-tujuan yang telah ditentukan (Martoyo, 1998). Efektivitas dalam aspek pencahayaan dapat diartikan sebagai pencapaian tujuan penggunaan pencahayaan. Dalam penelitian ini, lebih ditekankan kepada tujuan penggunaan pencahayaan alami.

Tujuan penggunaan pencahayaan alami terbagi menjadi kuantitas dan kualitas. Tujuan secara kuantitas adalah mengumpulkan cahaya dengan tingkat iluminasi yang cukup pada bidang kerja. Secara kualitas, tujuannya adalah membagikan cahaya secara merata ke seluruh ruangan, mencegah adanya perbedaan rasio kecerlangan yang berlebihan, dan meminimalisasi silau baik yang disebabkan oleh cahaya langsung maupun cahaya pantulan.

\section{Intensitas Cahaya}

Intensitas Cahaya adalah banyak arus cahaya yang diterima pada satu satuan luas permukaan. Faktor intensitas cahaya berpengaruh pada aktivitas yang dikerjakan pada suatu ruang. Pada penelitian ini, aktivitas yang dilakukan adalah aktivitas bekerja pada kantor.

Bangunan kantor merupakan bangunan yang membutuhkan pencahayaan yang baik agar pengguna dapat bekerja dengan efektif dan produktif. Pemanfaatan cahaya alami dalam kantor mengutamakan penggunaan cahaya bola langit (skylight), karena sinar matahari 
langsung (sunlight) akan membawa efek panas dan silau yang menyebabkan ketidaknyamanan.

Pencahayaan alami di Indonesia sudah memiliki standar intensitas cahaya/tingkat penerangan sebagai pedoman merancang bangunan, yaitu SNI 03-2396-2001 tentang tata cara perancangan sistem pencahayaan alami pada bangunan gedung dan SNI 03-6197-2000 tentang konservasi energi pada sistem pencahayaan.

\section{Kemerataan Cahaya}

Kemerataan cahaya merupakan faktor yang penting dalam kantor yang menjadi objek penelitian ini, karena cahaya alami juga digunakan sebagai general lighting yang mengharuskan cahaya terdistribusi dengan baik pada keseluruhan ruangan. Kemerataan cahaya dipengaruhi oleh sifat-sifat cahaya yaitu refleksi dan transmisi yang membantu pendistribusian cahaya di dalam ruang. Kemerataan cahaya dapat dinilai dengan mengukur tingkat iluminasi secara vertikal.

\section{Rasio Kecerlangan}

Rasio kecerlangan merupakan perbandingan kecerlangan antara suatu objek atau sumber cahaya dengan area sekitarnya. Kecerlangan menjadi relatif karena kecerlangan pada suatu benda tergantung kepada kecerlangan lingkungan di sekitarnya. Misalnya, kita berpendapat jika lampu mobil pada waktu malam sangat terang, dengan tingkat luminasi yang sama, pada siang hari lampu tersebut hanya terlihat terang biasa. Hal ini dikarenakan pada malam hari kecerlangan di sekitar lampu tersebut rendah dan pada siang hari kecerlangannya tinggi.

Menurut Szokolay (2004), untuk penglihatan yang baik rasio kecerlangan yang di anjurkan adalah bidang kerja:area sekitar:area latar $=1: 0,5 ; 0,2$. Area yang yang dimaksud dengan area bidang kerja (field of vision) adalah area dimana pengguna dapat melihat tanpa menggerakkan kepala atau mata, yaitu dengan derajat penglihatan $2^{\circ}$. Area sekitar (field of view) yang dimaksud adalah area yang dapat dilihat dengan hanya menggerakan mata tanpa menggerakkan kepala, yaitu dengan derajat penglihatan $40^{\circ}$. Area latar (background) yang di maksud adalah area yang dapat dilihat dengan menggerakkkan kepala tanpa menggerakkan badan, yaitu dengan derajat penglihatan vertikal $120^{\circ}$ dan $180^{\circ}$ secara horizontal.

Menurut, Lechner (2003), untuk penglihatan yang baik rasio kecerlangan yang di anjurkan untuk sumber cahaya (light source) dibandingkan dengan ruangan tempat pengguna berada (adjacent area) adalah 20:1.

\section{Silau}

Silau atau glare adalah gangguan visual yang mempengaruhi performa visual kegiatan. Silau dapat disebabkan oleh saturation effect dan kontras yang terlalu tinggi. Silau akibat saturation effect dapat terjadi apabila luminasi rata-rata dari jarak pandang lebih dari 25000 lux. Silau yang diakibatkan oleh kontras terjadi apabila rasio kecerlangan melebihi batas seharusnya sehingga menyebabkan kontras yang berlebihan, seperti yang telah dibahas pada poin rasio kecerlangan.

Ada dua macam silau, yaitu silau langsung dan silau pantulan yang masing-masing dapat berefek merugikan kemampuan untuk melihat baik itu sebatas discomfort maupun hingga mencapai disability untuk melihat

\subsection{LUBANG CAHAYA PADA RUANG KERJA DI RUMAH KINDAH OFFICE}

Secara umum, lubang cahaya pada ketiga ruang kerja yang menjadi ruang penelitian berorientasi ke timur-barat. Letak lubang cahaya yang berada di timur-barat ini dapat menjadi keuntungan dan kerugian. Keuntungannya cahaya matahari yang masuk didapat dengan 
maksimal sesuai dengan konsep bangunan yang menggunakan pencahayaan alami dan sama sekali tidak menggunakan pencahayaan buatan pada siang hari. Kerugiannya apabila tidak dirancang dengan baik dapat memberikan potensi silau dan ketidaknyamanan secara termal pada pengguna bangunan.

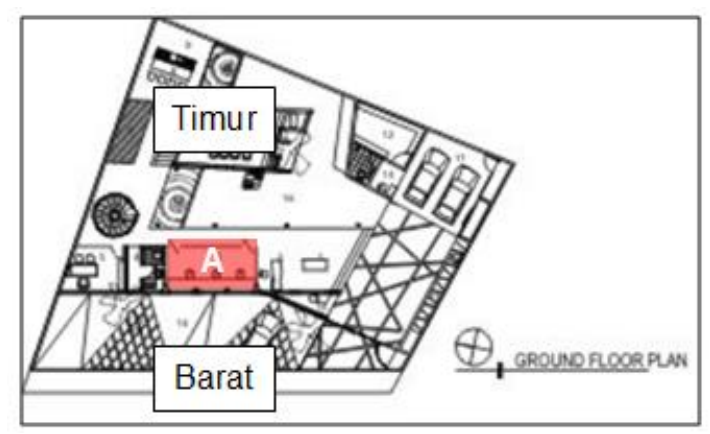

Figur 5. Posisi Ruang Kerja A

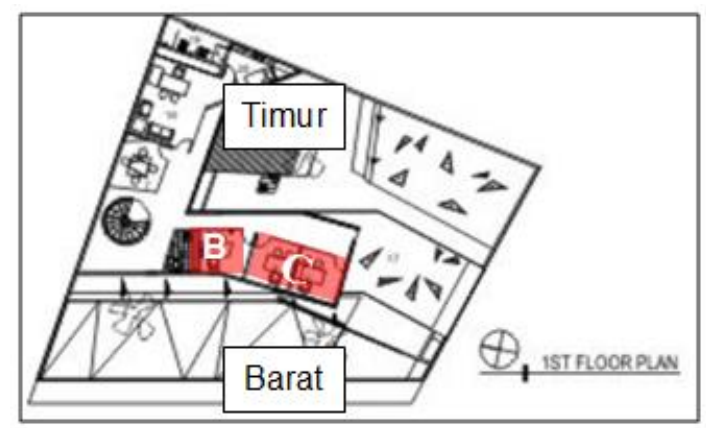

Figur 6. Posisi Ruang Kerja B dan C

Pada sisi timur di setiap ruang kerja, tedapat lubang cahaya berupa dinding kaca dengan spesifikasi yang berbeda setiap ruangnya.

Tabel 5. Lubang Cahaya Sisi TImur

\begin{tabular}{|c|c|c|}
\hline Ruang Kerja A & Ruang Kerja B & Ruang Kerja C \\
\hline \multicolumn{3}{|l|}{ Bentuk dan Dimensi } \\
\hline $\begin{array}{l}\text { Sidelighting pada sisi timur } \\
\text { berupa dinding kaca dengan } \\
\text { modifikasi motif kaca es dengan } \\
\text { kaca bening yang disesuaikan } \\
\text { dengan konsep bangunan yaitu } \\
\text { origami } \\
\text { Luas: } 13,1625 \mathrm{~m}^{2}\end{array}$ & $\begin{array}{l}\text { Sidelighting pada sisi timur } \\
\text { berupa dinding kaca dengan } \\
\text { penggunaan kaca bening. } \\
\text { Luas: } 6,86 \mathrm{~m}^{2}\end{array}$ & $\begin{array}{l}\text { Sidelighting pada sisi timur } \\
\text { berupa dinding kaca bening } \\
\text { Luas: } 14 \mathrm{~m}^{2}\end{array}$ \\
\hline \multicolumn{3}{|l|}{ Material } \\
\hline $\begin{array}{l}\text { Dinding kaca ini menggunakan } \\
\text { dua material berbeda yaitu kaca } \\
\text { polos dan kaca es. Kombinasi } \\
\text { kedua material tersebut } \\
\text { membentuk pola-pola tertentu. } \\
\text { Kaca polos yang digunakan } \\
\text { merupakan kaca polos dengan } \\
\text { tebal } 10 \mathrm{~mm} \text { dan mempunyai } \\
\text { transmisi 90\% dan refleksi } 6 \% \text {. } \\
\text { Selain itu, kaca es yang } \\
\text { digunakan mempunya transmisi } \\
78 \% \text { dengan refleksi } 12 \% \text {. Hal } \\
\text { ini menunjukkan bahwa pada } \\
\text { sisi timur, lubang cahaya } \\
\text { memiliki kemampuan yang } \\
\text { besar untuk meneruskan cahaya } \\
\text { dan kecil untuk pemantulan. }\end{array}$ & $\begin{array}{l}\text { Dinding kaca ini menggunakan } \\
\text { kaca polos. Kaca polos yang } \\
\text { digunakan merupakan kaca } \\
\text { polos dengan tebal } 10 \mathrm{~mm} \text { dan } \\
\text { mempunyai transmisi } 90 \% \text { dan } \\
\text { refleksi } 6 \% \text {. Hal ini } \\
\text { menunjukkan bahwa pada sisi } \\
\text { timur, lubang cahaya memiliki } \\
\text { kemampuan yang besar untuk } \\
\text { meneruskan cahaya dan kecil } \\
\text { untuk pemantulan. }\end{array}$ & $\begin{array}{l}\text { Dinding kaca ini menggunakan } \\
\text { kaca polos. Kaca polos yang } \\
\text { digunakan merupakan kaca } \\
\text { polos dengan tebal } 10 \mathrm{~mm} \text { dan } \\
\text { mempunyai transmisi } 90 \% \text { dan } \\
\text { refleksi } 6 \% \text {. Hal ini } \\
\text { menunjukkan bahwa pada sisi } \\
\text { timur, lubang cahaya memiliki } \\
\text { kemampuan yang besar untuk } \\
\text { meneruskan cahaya dan kecil } \\
\text { untuk pemantulan. }\end{array}$ \\
\hline
\end{tabular}




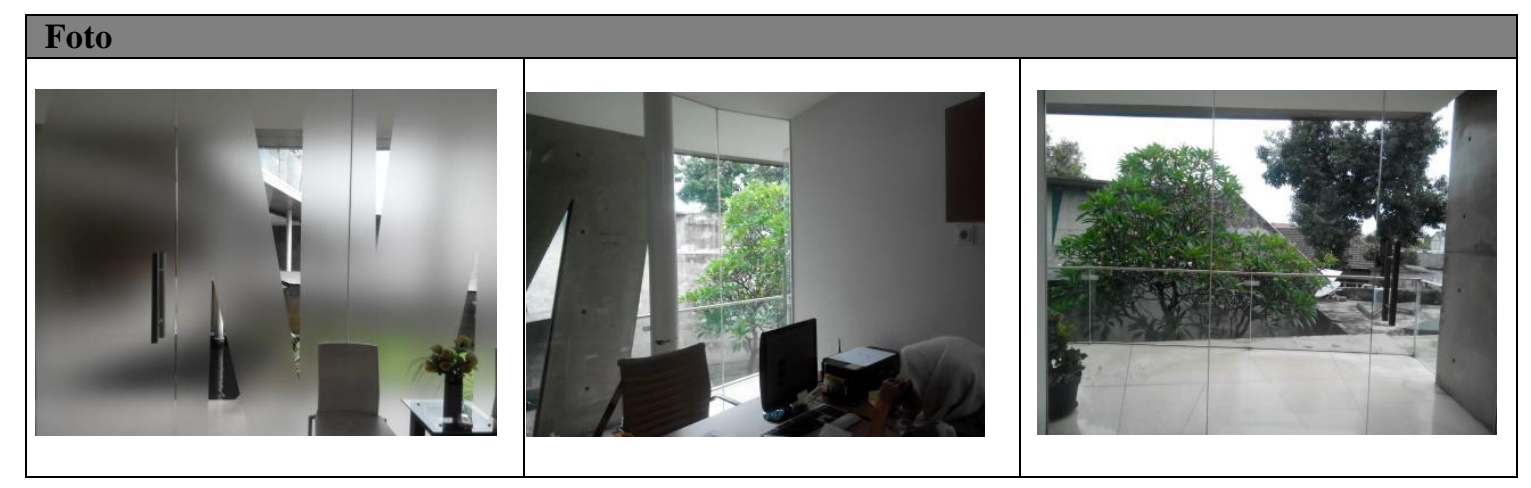

Pada sisi barat, ketiga ruang kerja memiliki lubang cahaya yang sama. Yang membedakan hanyalah jumlah dan posisinya terhadap bidang kerja.

Tabel 6. Lubang Cahaya Sisi Barat

\begin{tabular}{|l|l|l|}
\hline \multicolumn{1}{|c|}{ Ruang Kerja A } & Ruang Kerja B & Ruang Kerja C \\
\hline Bentuk dan Dimensi & \\
\hline
\end{tabular}



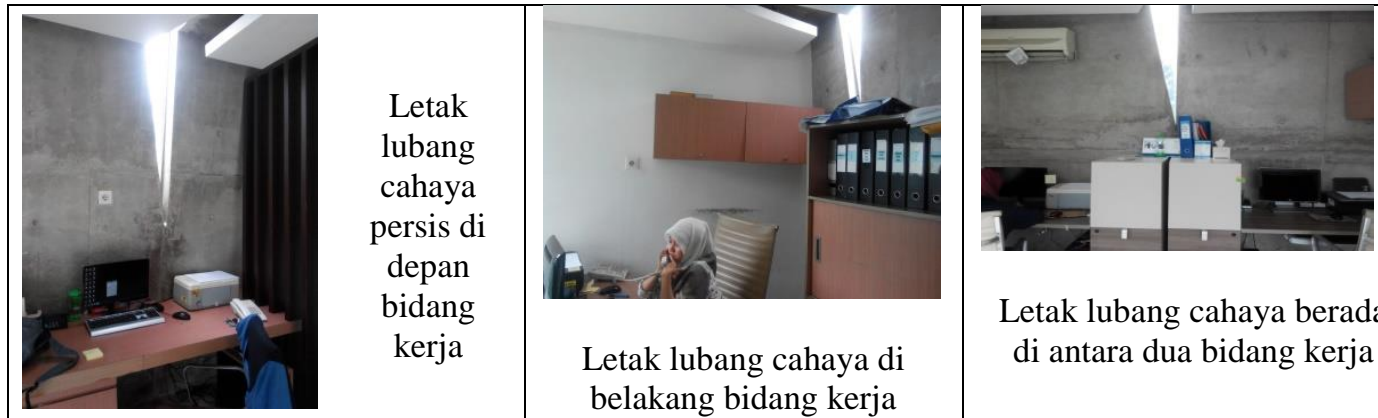

Letak lubang cahaya berada di antara dua bidang kerja

Material

Pada lubang cahaya ini material yang digunakan adalah kaca polos $10 \mathrm{~mm}$ dengan nilai transmisi $90 \%$ dan refleksi $6 \%$. Hal ini menandakan material ini hanya sedikit memantulkan cahaya dan sangat besar meneruskan cahaya.

\section{Bidang Refleksi pada Ruang Kerja di Rumah Kindah Office}

Bidang refleksi memberikan kontribusi terhadap penerusan cahaya yang jatuh pada bidang permukaan. Berikut material yang terdapat di ruang-ruang kerja yang dapat menjadi bidang refleksi:

Tabel 7 Bidang Refleksi Ruang Kerja

\begin{tabular}{|l|c|}
\hline \multicolumn{1}{|c|}{ Material } & Nilai Refleksi (\%) \\
\hline $\begin{array}{l}\text { Gypsum board berwarna putih dengan tekstur } \\
\text { halus. }\end{array}$ & $70-90$ \\
\hline $\begin{array}{l}\text { Teritis beton berwarna abu-abu dengan tekstur } \\
\text { cukup kasar }\end{array}$ & $20-30$ \\
\hline $\begin{array}{l}\text { Dinding beton berwarna abu-abu dengan tekstur } \\
\text { cukup kasar. }\end{array}$ & $20-30$ \\
\hline $\begin{array}{l}\text { Dinding dengan finishing cat putih dengan tekstur } \\
\text { halus }\end{array}$ & $80-90$ \\
\hline Keramik berwarna putih gading bertekstur halus. & $60-75$ \\
\hline $\begin{array}{l}\text { Kayu berwarna coklat muda dengan tekstur } \\
\text { cukup halus }\end{array}$ & $6-12$ \\
\hline
\end{tabular}

\section{Efektivitas Pencahayaan pada Ruang Kerja di Rumah Kindah Office \\ Intensitas Cahaya}

Tabel 8 Intensitas Cahaya Ruang Kerja A

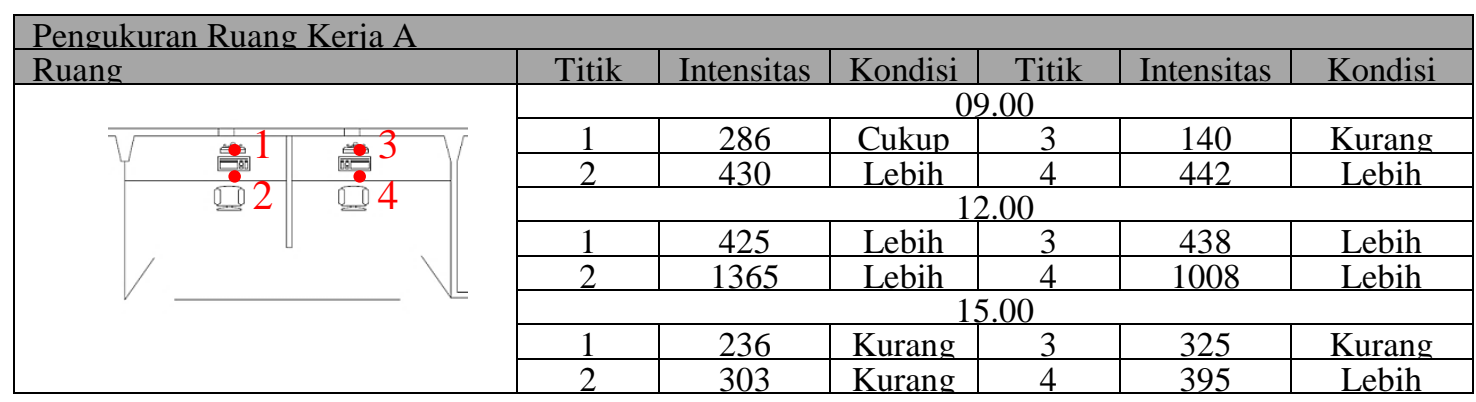


Tabel 9 Intensitas Cahaya Ruang Kerja A

\begin{tabular}{|c|c|c|c|}
\hline \multicolumn{4}{|l|}{ Pengukuran Ruang Keria B } \\
\hline Ruang & Titik ukur & Intensitas Cahava & Kondisi \\
\hline & \multicolumn{3}{|c|}{09.00} \\
\hline & 1 & 365 & Cukup \\
\hline & 2 & 415 & Lebih \\
\hline & \multicolumn{3}{|c|}{12.00} \\
\hline & 1 & 625 & Lebih \\
\hline & 2 & 890 & Lebih \\
\hline 0 & \multicolumn{3}{|c|}{15.00} \\
\hline & 1 & 345 & Cukup \\
\hline & 2 & 430 & Lebih \\
\hline
\end{tabular}

Tabel 10 Intensitas Cahaya Ruang Kerja C

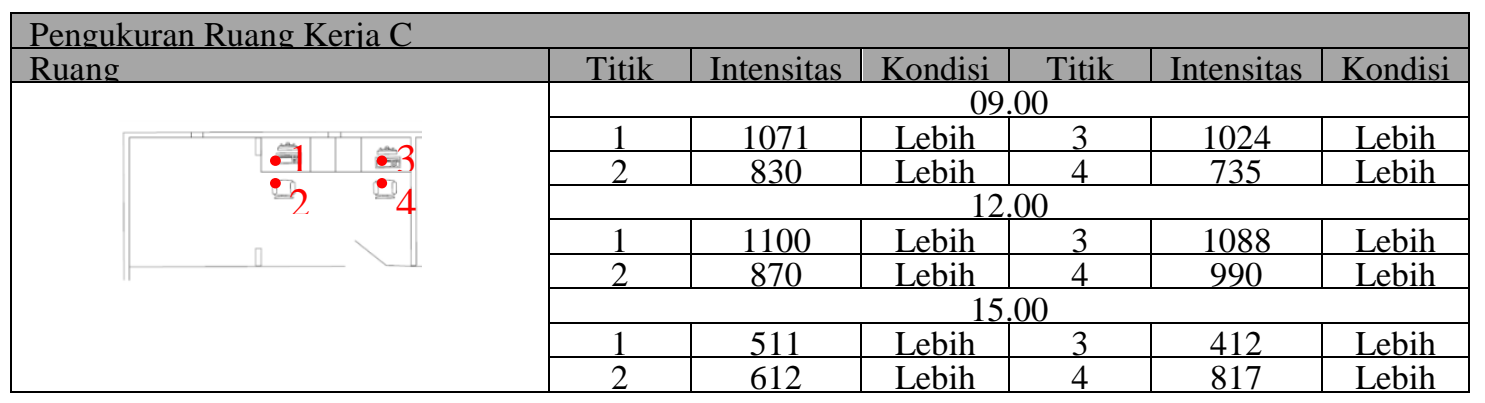

Efektivitas pencahayaan pada aspek intensitas cahaya diukur pada bidang kerja yang digunakan yaitu bidang kerja layar komputer dan bidang kerja meja.

Pada ketiga ruang yang diteliti, lubang cahaya secara garis besar berorientasi ke timur-barat. Orientasi timur-barat memberikan pengaruh cahaya yang masuk ke dalam ruangan memiliki intensitas yang tinggi karena merupakan sinar matahari langsung, namun posisi matahari yang bergerak dari timur ke barat juga menyebabkan ketinggian intensitas cahaya berpindah. Pada pagi hari sisi timur akan memiliki intensitas cahaya yang tinggi, sedangkan pada sore hari area yang tersinari oleh lubang cahaya sisi barat akan memiliki intensitas cahaya yang tinggi.

Jenis lubang cahaya yang digunakan pada ketiga ruang yang diteliti adalah side lighting dan top lighting. Side Lighting yang terletak pada sisi timur merupakan dinding kaca yang memiliki dimensi yang besar memberikan pengaruh cahaya yang masuk ke dalam ruangan menjadi banyak, terutama pada pagi hari. Side Lighting pada sisi barat merupakan jendela segitiga yang memiliki dimensi kecil sehingga cahaya yang masuk ketika matahari berada di barat merupakan cahaya yang terfokus pada titik tertentu namun memiliki intensitas yang tinggi pada titik tersebut. Titik fokus jatuhnya cahaya tersebut tidak jatuh di bidang kerja. Top lighting yang terletak di atas bidang kerja pada ruang kerja A.Meskipun dimensinya lebih kecil, namun cahaya yang masuk melalui top lighting adalah cahaya matahari langsung sehingga memiliki intensitas tinggi.

Dimensi lubang cahaya lebih dipentingkan ke fenestrasi. Pada ruang kerja A dengan posisi lubang cahaya segitiga tergolong ke dalam jendela tinggi. Ruang kerja A, B, dan $\mathrm{C}$ memiliki perbedaan pada posisi lubang cahaya terhadap bidang kerjanya. Pada ruang kerja A, posisi lubang cahaya segitiga yang berada persis di depan dan di atas bidang kerja membuat cahaya yang jatuh pada bidang kerja memiliki intensitas yang tinggi ketika siang hari. Pada ruang kerja $\mathrm{C}$, posisi lubang cahaya segitiga berada di antara dua bidang kerja sehingga cahaya yang jatuh di bidang kerja bukan cahaya langsung dari lubang cahaya segitiga. Ruang kerja $C$ terbantu oleh lubang cahaya dinding kaca yang memiliki luasan besar 
sehingga intensitas cahaya pada bidang kerjanya tinggi. Pada ruang kerja $\mathrm{B}$, posisi lubang cahaya segitiga berada di belakang bidang kerja. Hal ini membuat intensitas cahaya tinggi pada siang hari dan lebih rendah pada pagi hari. Cahaya banyak masuk melalui bidang kerja dinding kaca, namun karena posisinya berada di depan bidang kerja, ada kemungkinan memicu silau karena tingkat intensitasnya yang terlalu tinggi dibandingkan dengan bidang kerja.

Pada lubang cahaya segitiga, material yang digunakan pada tiap ruang kerja sama. Perbedaan terletak pada material yang digunakan pada lubang cahaya dinding kaca. Pada ruang kerja $\mathrm{B}$ dan $\mathrm{C}$ menggunakan kaca bening, sedangkan pada ruang kerja $\mathrm{A}$ menggunakan kombinasi antara kaca bening dengan kaca es. Perbedaan ini menyebabkan intensitas cahaya pada ruang kerja $\mathrm{A}$ lebih rendah dibandingkan ruang kerja $\mathrm{B}$ dan $\mathrm{C}$ karena nilai transmisi kaca es lebih kecil daripada kaca bening.

\section{Kemerataan Cahaya}

Tabel 11 Kemerataan Cahaya

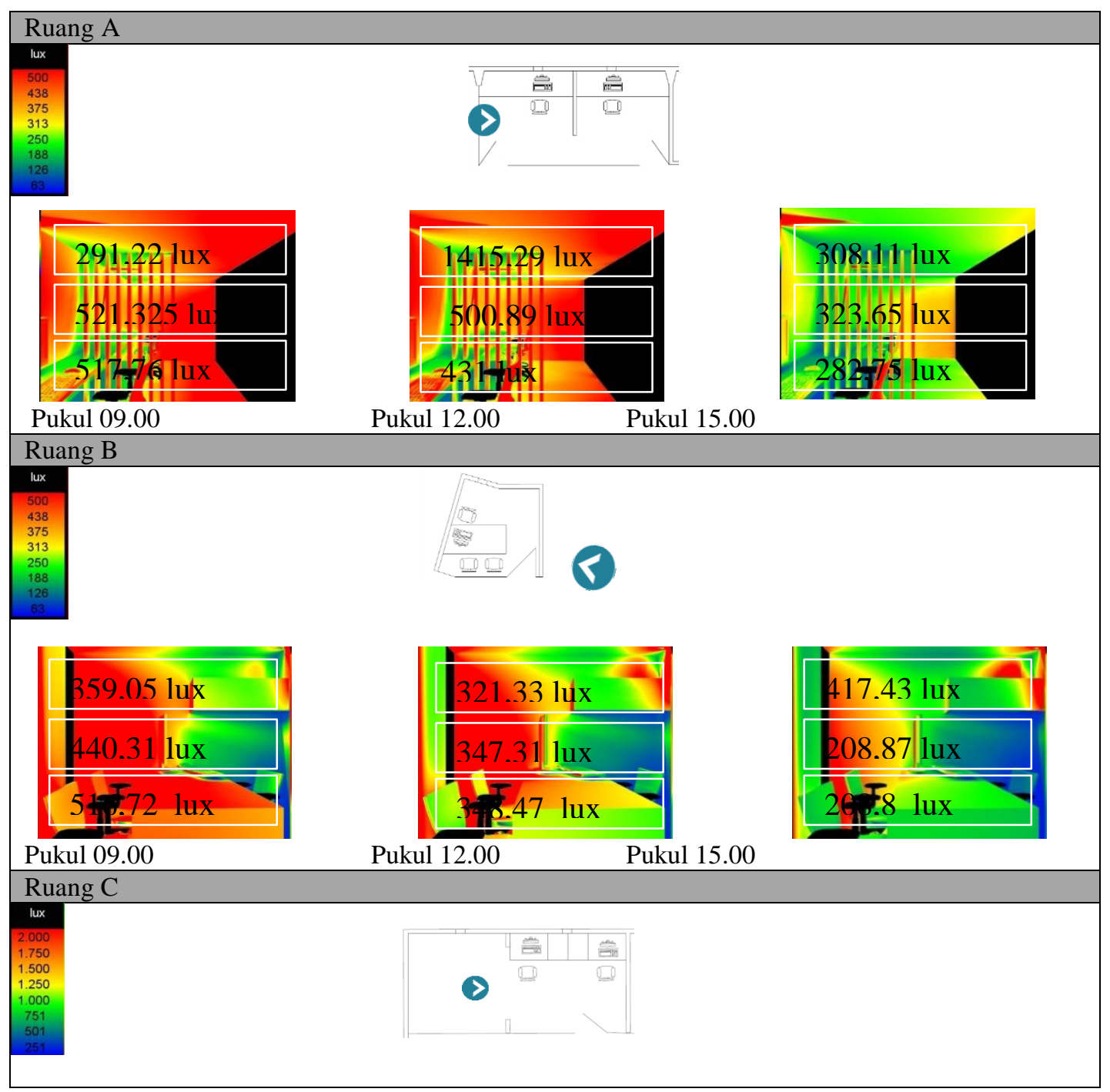




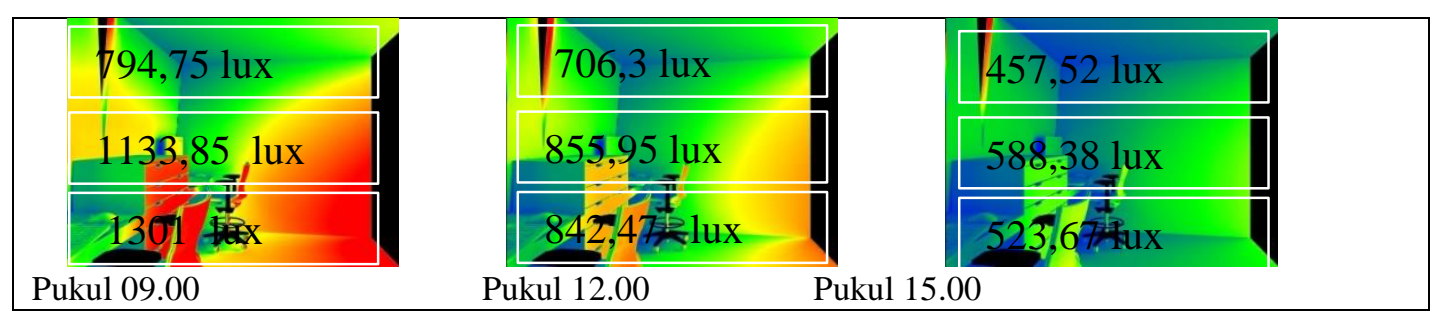

Pada objek penelitian, perpindahan posisi matahari tidak terlalu berpengaruh kepada kemerataan cahaya. Hal ini disebabkan karena dimensi lubang cahaya yang terdapat di dalam ruang kerja. Pada sisi timur, lubang cahaya pada tiap ruang kerja berupa dinding kaca sehingga dimensinya besar yang menyebabkan jumlah cahaya yang masuk lebih banyak daripada lubang cahaya sisi barat yang merupakan lubang cahaya segitiga dengan dimensi yang kecil. Terbukti dari hasil analisa, bahwa tingkat iluminasi yang paling tinggi dari terletak pada titik yang dekat dengan lubang cahaya timur yaitu dinding kaca, meskipun pengukuran dilakukan pada sore hari yang seharusnya posisi matahari berada di barat.

Lubang cahaya barat yang berupa lubang cahaya segitiga side lighting maupun top lighting berada pada posisi yang tergolong jendela tinggi. Sesuai dengan teori, jendela tinggi memberikan cahaya yang lebih efisien karena terletak di atas mata manusia. Berkaitan dengan kemerataan cahaya, efisien atau tidaknya posisi jendela tinggi ini dipengaruhi oleh bidang refleksi di sekitarnya.

Material yang digunakan pada lubang cahaya di objek penelitian mempengaruhi kemerataan cahaya dalam ruangan. Pada ruang kerja A, lubang cahaya sisi timur berupa dinding kaca menggunakan kombinasi kaca es dan kaca bening. Berdasarkan hasil analisa, penggunaan kombinasi material kaca es dan kaca bening ini membuat cahaya dalam ruang lebih merata. Dibandingkan dengan perbedaan tingkat iluminasi titik yang dekat dengan dinding kaca di ruang kerja lain, ruang kerja A cenderung lebih merata. Hal ini disebabkan kaca es merupakan bidang translucent yang melakukan transmisi dengan menyebarkan cahaya. Pada ruang kerja $\mathrm{B}$ dan $\mathrm{C}$ yang tidak menggunakan kaca es, pengukuran pada titik yang dekat dengan dinding kaca memiliki perbedaan yang cukup signifikan dengan titik ukur yang lain. Hal ini disebabkan karena dominasi dimensi lubang kaca yang tidak diberi kombinasi kaca es sehingga cahaya yang masuk terlalu banyak.

\section{Rasio Kecerlangan dan Silau}

Tabel 12 Simulasi Luminasi Ruang Kerja A

\begin{tabular}{|c|c|c|}
\hline \multicolumn{2}{|c|}{ Simulasi Ruang A Bidang kerja layar komputer } \\
\hline Cd/m2 \\
\hline 100 \\
88 \\
75 \\
63 \\
50 \\
38 \\
26 & & \\
\hline & & \\
\hline
\end{tabular}




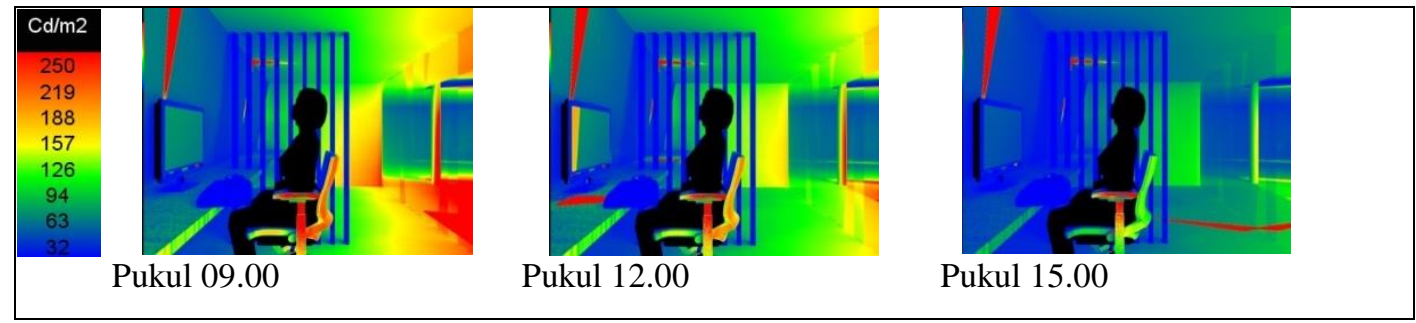

Tabel 13 Simulasi Luminasi Ruang Kerja B

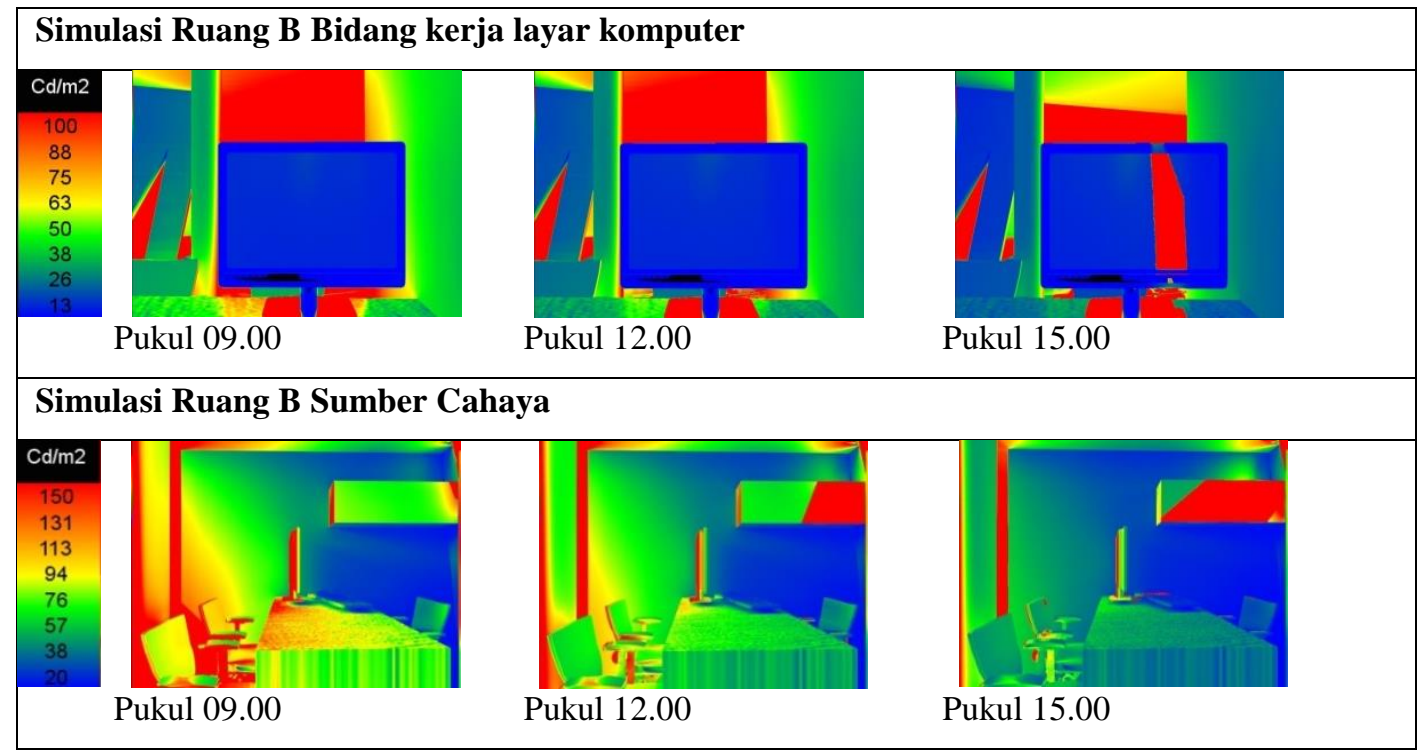

Tabel 14 Simulasi Luminasi Ruang Kerja C

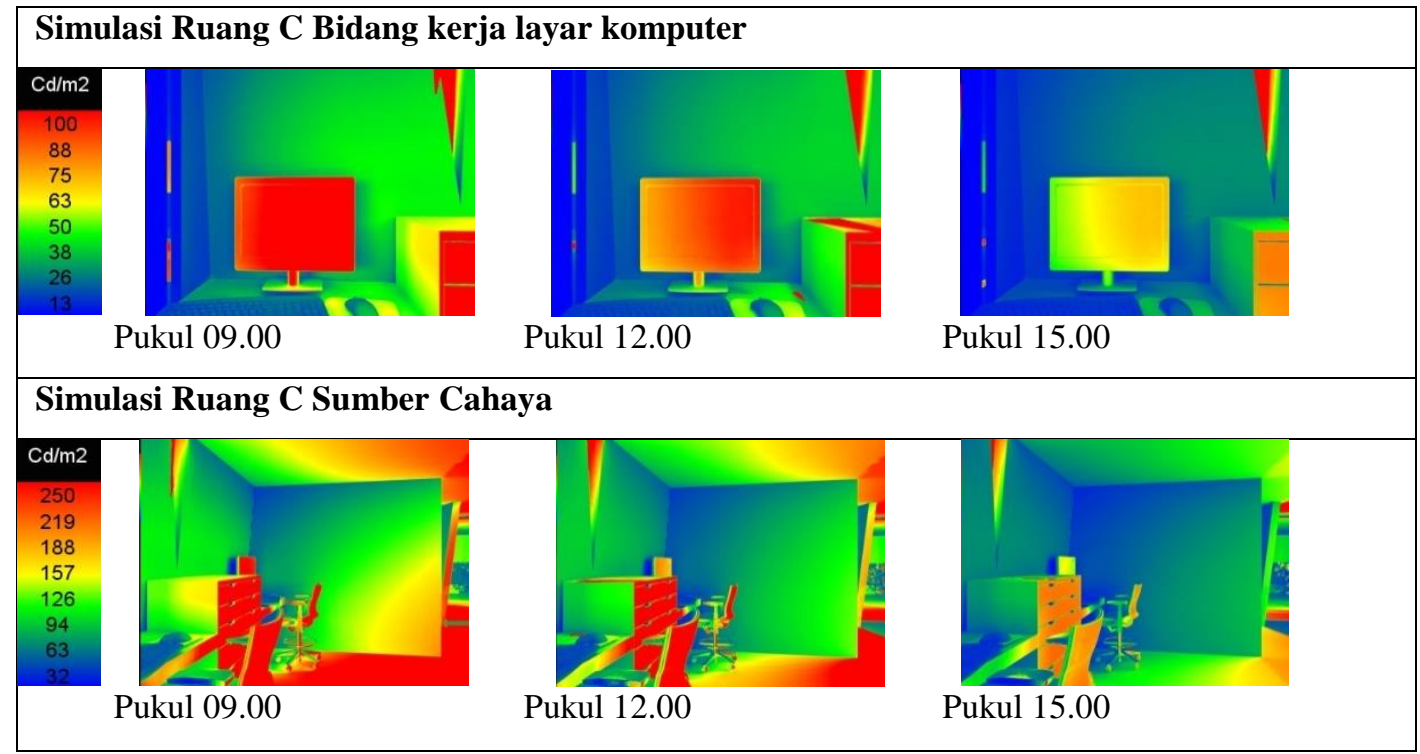


Dari simulasi yang dilakukan maka di dapatkan efektivitas dari tiap ruangan adalah sebagai berikut:

Tabel 15 Efektivitas Luminasi Ruang

\begin{tabular}{|c|c|c|c|}
\hline & Intensitas Cahaya & Kemerataan Cahaya & $\begin{array}{c}\text { Rasio Kecerlangan dan } \\
\text { Silau }\end{array}$ \\
\hline 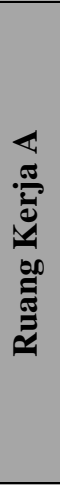 & $\begin{array}{l}\text { Intensitas cahaya di ruang } \\
\text { kerja A cenderung lebih } \\
\text { dari standar yang ada pada } \\
\text { pagi dan siang hari, } \\
\text { sedangkan kurang dari } \\
\text { standar yang ada pada sore } \\
\text { hari. }\end{array}$ & $\begin{array}{l}\text { Cahaya di ruang kerja Adap } \\
\text { at dikatakan cukup merata } \\
\text { dengan area yang dekat } \\
\text { dengan dinding kaca selalu } \\
\text { berada di tingkat iluminasi } \\
\text { yang paling tinggi. }\end{array}$ & $\begin{array}{l}\text { Rasio kecerlangan di ruang } \\
\text { kerja A cenderung } \\
\text { memenuhi standar, kecuali } \\
\text { pada pagi hari terhadap } \\
\text { sumber cahaya timur rasio } \\
\text { kecerlangan cukup tinggi } \\
\text { sehingga memicu silau. } \\
\text { Pada siang hari terdapat } \\
\text { kasus silau khusus dimana } \\
\text { terdapat cahaya yang jatuh } \\
\text { pada titik } \\
\text { tertentu di bidang kerja. }\end{array}$ \\
\hline 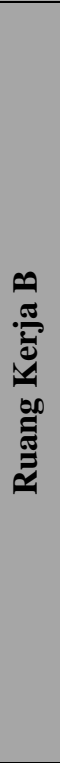 & $\begin{array}{l}\text { Intensitas cahaya di ruang } \\
\text { kerja B cenderung lebih dari } \\
\text { standar yang ada pada } \\
\text { bidang kerja layar } \\
\text { komputer, sedangkan untuk } \\
\text { bidang kerja meja intensitas } \\
\text { cahaya melebihi standar } \\
\text { ketika siang hari. }\end{array}$ & $\begin{array}{l}\text { Cahaya di ruang kerja B } \\
\text { dapat dikatakan tidak } \\
\text { merata, melihat perbedaan } \\
\text { tingkat iluminasi yang } \\
\text { cukup signifikan antara area } \\
\text { yang dekat dengan dinding } \\
\text { kaca dan area yang lebih } \\
\text { dalam. }\end{array}$ & $\begin{array}{l}\text { Rasio Kecerlangan di ruang } \\
\text { kerja B memiliki beberapa } \\
\text { masalah. Pada pagi hari } \\
\text { rasio kecerlangan terhadap } \\
\text { bidang kerja layar komputer } \\
\text { dan sumber cahaya timur } \\
\text { tidak memenuhi standar } \\
\text { sehingga memicu silau. } \\
\text { Pada siang hari, rasio } \\
\text { kecerlangan terhadap } \\
\text { sumber cahaya barat } \\
\text { melebihi standar. Pada sore } \\
\text { hari, terdapat kasus dimana } \\
\text { cahaya jatuh terfokus pada } \\
\text { titik tertentu di bidang kerja } \\
\text { dan memiliki rasio } \\
\text { kecerlangan yang tidak } \\
\text { memenuhi standar sehingga } \\
\text { memicu silau. }\end{array}$ \\
\hline 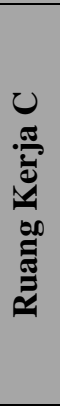 & $\begin{array}{l}\text { Intensitas cahaya di ruang } \\
\text { kerja C selalu lebih dari } \\
\text { standar yang ada pada } \\
\text { semua bidang kerja. }\end{array}$ & $\begin{array}{l}\text { Cahaya di ruang kerja C } \\
\text { dapat dikatakan tidak } \\
\text { merata, melihat perbedaan } \\
\text { tingkat iluminasi yang } \\
\text { sangat signifikan antara } \\
\text { area yang dekat dengan } \\
\text { dinding kaca dan area yang } \\
\text { lebih dalam. }\end{array}$ & $\begin{array}{l}\text { Rasio kecerlangan di ruang } \\
\text { kerja C cenderung } \\
\text { memenuhi } \quad \text { standar. } \\
\text { Permasalahan hanya } \\
\text { terletak pada pagi hari, rasio } \\
\text { kecerlangan area dalam } \\
\text { ruangan dengan sumber } \\
\text { cahaya timur lebih dari } \\
\text { standar yang ada sehingga } \\
\text { memicu silau. }\end{array}$ \\
\hline
\end{tabular}

Orientasi timur-barat menyebabkan cahaya yang masuk melalui lubang cahaya dapat berupa cahaya matahari langsung. Cahaya matahari langsung memiliki intensitas yang lebih tinggi dibanding cahaya langit. Di ruang-ruang kerja pada pagi hari intensitas cahaya sumber cahaya dari timur sangat tinggi dan cahaya masuk melalui dinding kaca yang memiliki dimensi yang besar. Perbedaan tingkat kecerlangan antara sumber cahaya dan ruangan ini menyebabkan silau apabila pengguna melihat ke sumber cahaya. Fenestrasi yang tinggi dinding kaca menyebabkan cahaya yang masuk terlalu tinggi. Selain itu pada siang hari, cahaya masuk dari top lighting berupa cahaya matahari langsung. Pada ruang kerja A dan C, bidang kerja yang terletak persis di bawah top lighting pada siang hari terkena pancaran 
cahaya matahari langsung dengan intensitas yang tinggi. Dimensi top lighting yang kecil dan tidak adanya bidang refleksi di sekitar top lighting mempengaruhi cahaya yang jatuh terfokus pada titik tertentu dan terkena di area bidang kerja. Pada sore hari, cahaya matahari langsung masuk melalui side lighting sisi barat berupa lubang cahaya segitiga. Pada ruang kerja $\mathrm{B}$, posisi bidang kerja yang membelakangi lubang cahaya membuat cahaya yang masuk dari side lighting merupakan cahaya matahari langsung sehingga intensitasnya tinggi. Cahaya yang masuk terfokus pada titik tertentu pada bidang kerja yang menyebabkan rasio kecerlangan antara bidang kerja dengan titik tersebut tinggi dan dapat memicu silau.

Material yang digunakan pada lubang cahaya didominasi oleh kaca bening yang memiliki nilai transmisi yang besar sehingga cahaya yang masuk pun besar sesuai dengan sumber cahayanya. Hal ini menyebabkan pada pagi hari apabila melihat ke arah timur dan melihat ke lubang cahaya segitiga pada sore hari akan memicu silau. Material kombinasi berupa kaca es pada ruang kerja A membantu menyebarkan cahaya sehingga cahaya yang melewati material kaca es ini memiliki intensitas yang lebih kecil namun menyebar.

\section{PENUTUP}

\subsection{KESIMPULAN}

Lubang cahaya dan bidang refleksi memberikan pengaruh yang besar terhadap intensitas cahaya yang jatuh pada bidang kerja, kemerataan cahaya dalam ruang, rasio kecerlangan pada bidang kerja maupun sumber cahaya serta menentukan potensi silau. Lubang cahaya memberikan pengaruh akibat orientasi, jenis, posisi, dimensi dan material, sedangkan bidang refleksi memberikan pengaruh dari nilai refleksinya.

\section{DAFTAR PUSTAKA}

Baker, Nick. V. 1993. Daylighting in Architecture. London: Routledge.

Evans, Benjamin H. 1981. Daylight in Architecture. United States of America : McGraw-Hill Inc.

Brown, G.Z. 1990. Matahari, Angin, dan Cahaya - Strategi Perancangan Arsitektur. Bandung: Intermatra.

Lam, William M. C. 1992. Perception and Lighting as Formgivers for Architecture. United States of America.

Lechner, N. 2015. Heating, Cooling, Lighting, Desing Methods for Architect 4th edition. United States of America: Joohn Willey and Sons Inc.

Mangunwijaya, YB, Dipl. Ing. 2000. Pasal-pasal Penghantar Fisika Bangunan. Jakarta: Djambatan.

Manurung, Pamonangan. 2012. Pencahayaan Alami dalam Arsitektur. Yogyakarta: Andi Offset.

Martoyo, Susilo. 1998. Pengetahuan Dasar Managemen dan Kepemimpinan. Yogyakarta: BPFE.

Satwiko,Prasasto. 2009. Fisika Bangunan. Yogyakarta : Andi Offset.

Sugijanto. 1999. Bangunan di Indonesia dengan iklim tropis lembab ditinjau dari aspek fisika bangunan. Jakarta : Depdikbud

Szokolay, Steven. V. 2004. Introduction to Architectural Science: the basis of sustainable design. Oxford.

Tim Penyusun. 2001. SNI 03-2396-2001 Tata Cara Perencanaan Sistem Pencahayaan Alami Pada Bangunan Gedung. Jakarta: Badan Standardisasi Nasional.

www.kbbi.web.id

www.google.co.id 